\title{
Investigation of the Effect of Focusing on Customers, Knowledge Management, Organizing Business Processes and Up-to-Date Technologies on Establishment of Customer Relationship Management in Iranian Insurance Firms
}

\author{
Ghalandari Kamal * \\ Department of Business Management, Qazvin Branch, Islamic Azad University, Qazvin, Iran \\ *Corresponding Author: E-mail:kamal.ghalandari@gmail.com
}

\begin{abstract}
Today, presence of a strong relationship with customers is among the most important success factors in every business. So concept of customer relationship management (CRM) meaning organizational efforts to create and provide customer value has attracted significant attention; thus, the purpose of this paper is to investigate factors influencing on establishment of customer relationship management in Iranian insurance firms. Totally, 250 questionnaires were distributed to managers and experts of insurance firms of Tehran city, that 230 questionnaires were used for the final analysis, which the results from analysis of them based on simple linear regression and Friedman test show that four factors including focusing on key and main customers, paying attention to knowledge management, organizing business processes and having modern and up-to-date technologies are influential in establishment of customer relationship management in Iranian Insurance Firms.
\end{abstract}

Keywords: Customer, Customer relationship management (CRM), Knowledge management, Organizing business processes, Technologies.

\section{Introduction}

Today, organizations operate in a customeroriented environment in which customer is the real ruler of market. Thus organizations should learn that how to shift from product or service orientation towards customer orientation. They should consider customers as an asset requiring management and maximization of its return. Since organizations have recognized that customers are their most important assets, so they consider customer relationship as a profitable interaction requiring correct management [1]. Today competitive world has forced organizations to pay more attention to customers and focus on customers and their satisfaction rather than mass production. Desire of business world for differentiating products and services has been replaced with customer focus and this leads to emergence of a new one to one philosophy in such a way that organization creates relationship with customer and maintains its relationship in a profitable and effective way [2].In CRM process it is tried to identify, attract and retain most profitable customers in the best way. CRM is a continuous process consisting of creation and employment of market science and intelligence in order to create and retain a set of customer relationships having the most return [3]. Previous research shows that establishment of CRM leads to increased income, increased Ghalandari |July.-Aug. 2012 | Vol.1 | Issue 4|42- 47 competitive capability, and decreased operational costs in many organizations. Effective and efficient CRM results in increased satisfaction and loyalty of customers. Given the appearance of private insurance firms since 2003 and multiplicity of firms providing insurance services, firms operating in this industry witness increased and intense competition for achieving a higher status in state insurance market. On the other hand, according to great number of insurance firms, customers have many choices for conducting their insurance works. In such conditions, there is a broad competition among insurance firms for attracting new customers, retaining existing customers and creating loyal customers and success in such a competitive market requires enhancing quality of insurance services, upgrading customer satisfaction level and attracting and retaining customers. According to significance of CRM in attraction and retention of customers and also given the competitive conditions of Iranian insurance industry, present study seeks to identify factors influencing successful establishment of CRM in insurance firms so that in this way a proper ground is prepared for increasing satisfaction and loyalty of customers through creation of effective communications and attracting and retaining customers and in this way stakeholders of 
insurance firms may witness increase in their market share and more profitability compared to their competitors.

\section{Literature Review}

\section{Customer Relationship Management (CRM)}

Various definitions have provided for customer relationship management (CRM) by scholars. One group considers it as a strategy, another one as a technology and again other one as an information system [4]. CRM consists of methodologies, processes and software which help in establishment of an organized relationship with customers [5].CRM means to create and maintain a specified relationship with profitable customers through using appropriate information and communication technology [2].CRM, as a process, consists of customer monitoring, collecting appropriate data, data management and evaluation and finally derivation of real advantages from information extracted from customers interactions [6].CRM is one type of marketing strategy which its purpose is not to increase profits only in short term but it aims to increase customer satisfaction and profits in long term [7].CRM is a customer-oriented organizational model which uses customer information in order to create a customized strategy so that it can increase customer loyalty level and decrease operational costs by identifying customer demands [8].Given the mentioned definitions, CRM is the process of designing an organization around customers which considers developing sales and marketing applied software and integrating them at operational level and addresses the way of creating and maintaining long term relationships and the way of formulating strategies and policies for achieving them in another level. CRM is an approach at entire organizational level, not only for obtaining knowledge about customers but also for improving and automating work processes creating value for customers, suppliers and employees of organization [9].According to the research conducted up to now it seems that CRM is a multi-dimensional concept consisting of four parts of strategy, people, technology and processes [10]. In one comprehensive study on factors influencing establishment of CRM, Sin et al. [11] concludes that success of CRM depends upon four factors of focusing on key and main customers, paying attention to knowledge management, organizing business processes and having modern and up-todate technology. In the following each of them are explained.

\section{Focusing on Key and Main Customers}

Focusing on key and main customers includes intensive attention of organization to customers, providing excellent and creating added-value for customers through providing customized services which in turn consists of such parts as customeroriented marketing, customer life cycle value, customization and interactive marketing [12].Customer-oriented marketing means to exert efforts to understand and meet demands of a particular group of customers. CRM intensively emphasizes on choosing key customers of organization. Key customers are ones who are of more importance for organization from strategical viewpoint and are more profitable [13]. Customer life cycle value consists of net income from customer minus costs of attraction, sales and providing services to customers with respect to value of money at that time. On this basis, organizations make decisions on having relationships with a certain customer and providing personal services to him \her [14]. Personalization allows customers to meet their specific demands by receiving unique services according to their diverse demands [15]. In interactive marketing customers play roles in various parts of designing, producing and providing products and services and this leads to strengthened relationships between firm and customer and more loyal customer [11].

\section{Knowledge Management}

From perspective of knowledge management, a firm exists mainly to create, transfer and employ knowledge. Knowledge can be acquired by understanding experiences and information of customers. Main aspects of knowledge management are knowledge creation, knowledge sharing and accountability. Knowledge on main customers is necessary for a successful CRM because it can lead to creation a learning relationship with customer and increases organizational competitiveness significantly. Information on customers can be acquired through mutual communication. Business intelligence tools e.g. data mining and data warehouse enable firms to employ customer information in strategic business intelligence [7]. Organizations should facilitate coordinating activities across various parts of organization by offering mechanisms for knowledge sharing. Accountability is considered as the effect of knowledge creation and sharing which includes choosing target segments, creation of marketing mixture based on customer interest and providing services to meet present and future demands of customers [11]. 


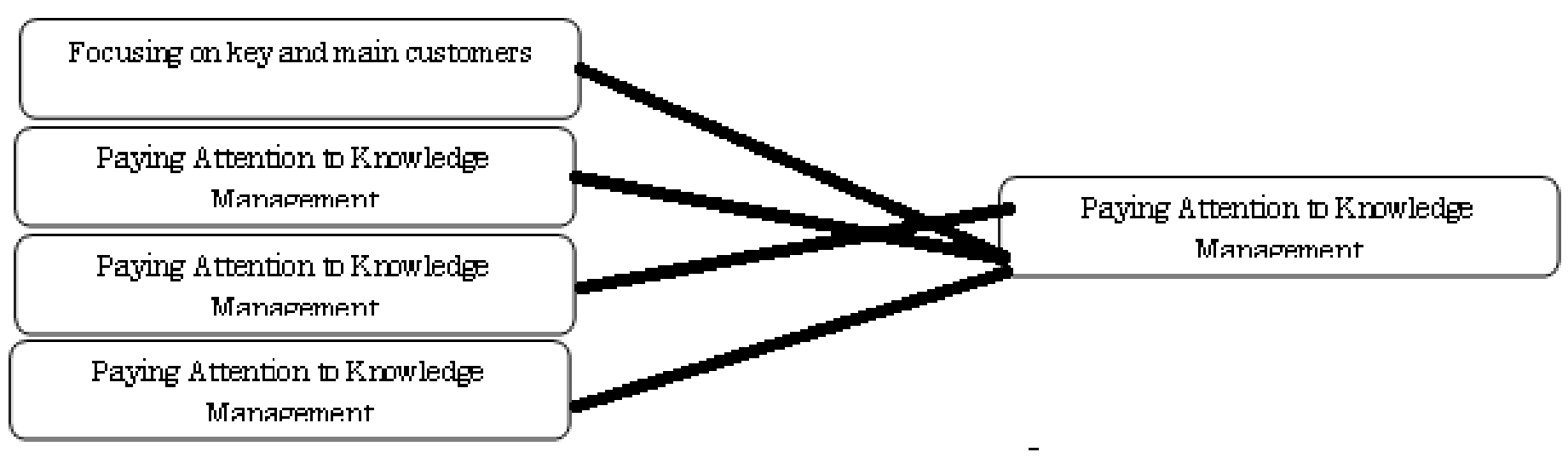

Fig. 1: The conceptual model for research

\section{Organizing Business Processes}

Conducting CRM process needs to changes in organizing manner, structure and business processes. In this respect, organizational structure, organizational commitment and human resource management (HRM) should be considered [16]. CRM success requires moving the whole organization towards a common goal. For this purpose, a favorable organizational structure needs creation of work teams, customer-focused teams, coordinating teams and multi-functional teams which demands coordination and integration across various parts of organization [11]. The issue being considered after addressing organizational structure is commitment at the whole organizational level. In this respect it is necessary for organization to have required tools in sales, marketing and technical expertise as well as other resources. Success in attracting and retaining customers depends upon commitment of all various organizational resources to identification and meeting of key customers' needs [17]. Though various factors of strategy, people, technology and processes are of major importance in successful implementation of CRM, but employees are ones who play the essential role in creating relationship with customers. The most challenging part in the way towards turning into a customer-oriented organization is organizational people rather than modern technologies. Internal marketing recalls employees to consider customers as more important as possible [18].

\section{Having Modern and Up-to-Date Technologies}

Having correct information on customers is necessary for successful establishment of CRM and technology plays an essential role in enhancing firm intelligence. Indeed, unprecedented progress in information technology along with capability of gathering, storing, analyzing and sharing information promote ability of organization to react to needs of all individual customers. Sophisticated technologies make it possible to establish one-to-one communications, to analyze customer-value, to integrate customer information system, to automate processes and to customize services [19]. Computer technologies are exploited in creating communications and aligning technologies with business goals. Using CRM software enables firms to offer customized services with higher quality and lower cost. Also it helps employees to perform better in interacting with customers [11].

\section{Research Hypothesis}

Based on the facts raised in research theoretical framework section, the following hypotheses are addressed:

H1: Focusing on key and main customers is effective in establishment of CRM in insurance firms.

H2: Paying attention to knowledge management is effective in establishment of CRM in insurance firms.

H3: Organizing business processes is effective in establishment of CRM in insurance firms.

H4: Having modern and up-to-date technology is effective in establishment of CRM in insurance firms.

Therefore, based on the hypothesis, figure 1 is a conceptual model to this study.

\section{Methodology}

\section{Procedure and Questionnaire Design}

Data collection instrument was a questionnaire consisting of 40 questions organized based on four dimensions of focusing on key and main customers, paying attention to knowledge management, organizing business processes and having modern and up-to-date technology and subjects rated the effect of each measure on success of CRM establishment. Answering the questions was based on Likert five-point scale and choices provided for answering each question 
included too little, little, moderate, much and very much. Also in the first part of questionnaires the responders were asked to give information on their age, gender, education and work experience.Respecting to the fact that the questionnaire used in present research was developed based on both research background and opinions of relevant experts, thus it has content validity. In order to verify reliability of questionnaire, Cronbach a coefficient was used. Cronbach a was estimated at 95\% which demonstrated questionnaire reliability. Also as Table 1 shows, Cronbach a coefficient was estimated at above 0.07 for all dimensions.

Table 1: Cronbach a coefficient estimated for various dimensions

\begin{tabular}{|l|l|}
\hline \multicolumn{1}{|c|}{ Dimensions } & $\mathbf{\alpha}$ \\
\hline Focusing on key and main customers & 0.786 \\
\hline Paying attention to knowledge management & 0.935 \\
\hline Organizing business processes & 0.934 \\
\hline Having modern and up-to-date technologies & 0.936 \\
\hline The whole questionnaire & .956 \\
\hline
\end{tabular}

\section{Research Sample}

Statistical population of it consists of managers and experts of insurance firms of Tehran city which amounts to 550 persons. Sample volume was estimated at 226 subjects at confidence level of $95 \%$ and accuracy of $0.07 \%$ and the sample was chosen using simple random method in June 2012.

\section{Data Analysis}

In order to examine hypotheses, regarding to significance values and $t$-value in original regression analysis table (table 2), it is judged that if sig. value is less than research error coefficient value, i.e. 0.05 , and also t-value is more than 1.96 or less than -1.96 , then the related hypothesis will be supported with a CI confidence intervals of $95 \%$.

\section{Results and Discussion}

\section{Hypothesis Testing}

Hypothesis 1: Findings of original regression analysis table ( $\mathrm{t}$-value $=2.830 ; \mathrm{sig}=0.005)$ in relation to hypothesis 1 show that focusing on key and main customers is effective in establishment of CRM in insurance firms; thus hypothesis 1 is supported.

Hypothesis 2: Findings of original regression analysis table ( $\mathrm{t}$-value $=8.330 ;$ sig $=0.000)$ in relation to hypothesis 2 show that paying attention to knowledge management is effective in establishment of CRM in insurance firms; thus hypothesis 2 is supported.

Hypothesis 3: Findings of original regression analysis table $(\mathrm{t}$-value $=5.186 ;$ sig $=0.000)$ in relation to hypothesis 3 show that organizing business processes is effective in establishment of CRM in insurance firms; Thus hypothesis 3 is supported.

Hypothesis 4: Findings of original regression analysis table ( $\mathrm{t}$-value $=8.800 ;$ sig $=0.000)$ in relation to hypothesis 4 show that having modern and up-to-date technology is effective in establishment of CRM in insurance firms; Thus hypothesis 4 is supported.

Therefore it is concluded that four factors of focusing on key and main customers, paying attention to knowledge management, organizing business processes and having modern and up-todate technology are influential in establishing CRM in insurance firms.

\section{Conclusion}

Results from examining $\mathrm{H} 1$ show that focusing on key and main customers has effect on establishment of CRM in insurance firms. Oligvy [20] also showed that focusing on customers is effective in successful establishment of CRM. This includes identification of needs, behaviors and life cycle of customers and customer analysis and also it requires employing this information in creating customer value.

Findings obtained from examination of $\mathrm{H} 2$ shows that paying attention to knowledge management is effective in successful establishment of CRM in insurance firms. Success of knowledge management requires an appropriate combination of processes, people and information technology. Capability of data storing is a major factor in enabling knowledge management. Knowledge obtained about customers can empower the organization in making intelligent decisions on customer attraction, development of relationships and creation of appropriate communicational channels [21]. Knowledge management systems also support collecting, distributing and using such information as documents and implicit knowledge of employees. Also Azari in his research concluded that knowledge management was effective in successful establishment of CRM [22].Based on results from examination of $\mathrm{H} 3$, organizing business processes is effective in CRM establishment in insurance firms. Oligvy [20] and Azari [22] also in their research concluded that reviewing and designing new processes are necessary in implementation of CRM. Firms should define their business goals and needs and develop processes related to CRM in order to meet those needs. Findings from examination of $\mathrm{H} 4$ show that having modern and up-to-date 
Table2: Results of original regression analysis table

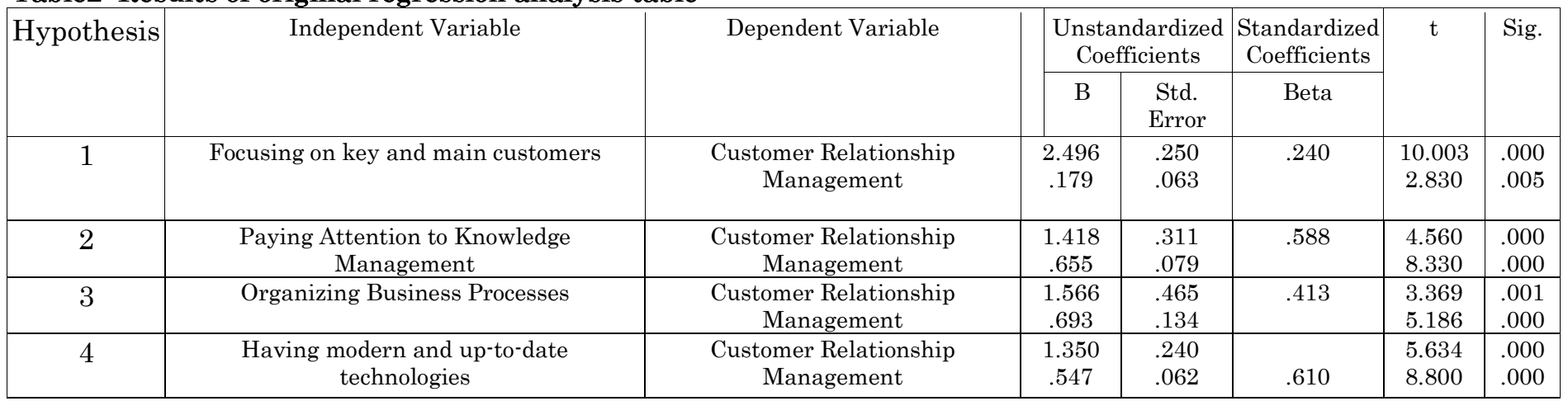

technologies is effective in establishment of CRM in insurance firms. Other research also emphasized the importance of modern and up-todate technologies on success of CRM. Curry [23] and Chen [24] also concluded that employing new technologies is effective in CRM establishment and it requires some changes in organizational infrastructure and employment of novel technologies. New technologies have changed the relationship between customers and firms. Virtual environments have developed for supporting interactions and continuous information exchange and software packages offer a variety of technologies to customers without respect to communication channel.

\section{Applied Recommendations}

Based on research findings which demonstrate effectiveness of four factors of focusing on key and main customers, paying attention to knowledge management, organizing business processes and having modern and up-to-date technologies in establishment of CRM in insurance firms, following recommendations are provided in order to upgrade readiness level for implementing CRM in a successful way:

- Formation of service channel evaluation team: this team coordinates customer, services and various communicational routes and enhances it. Another task of this team is to create a single image of organization for customers through coordination of various channels e.g. contact centers, internet and public relations unit.

\section{References}

1. Plakoyiannaki E (2005) How do organisational members perceive CRM? Evidence from a U.K.service firm. J. Marketing Management, 21:363-92.

2. Payne A, Frow P (2004) The role of multi channel integration in customer relationshipmanagement. Industrial Marketing Management 33:527-38.

3. Zablah AR, Bellenger DN, Bellenger DN and Johnston WJ (2004) An evaluation of divergent perspectives on customer relationship management: Towards a common understanding of an emerging
- Formation of market segmenting team: this team acts as a linking agent in CRM process. Tasks of this team consist of: managing interactions between customer and organization, determining relational and behavioral patterns, managing privacy of customers in organization.

- Formation of a team for examination of CRM activities: after identifying opportunities, this team starts to provide right services to target customers and formulate and review CRM strategies. Among other tasks of this team, trial evaluation of new services may be pointed out.

- Formulating strategic plan for timely starting and ending CRM implementation project in order to prevent deviation of project team and coordinate subsystems.

- Enhancement and development of information and communication technology management in the form of establishing horizontal and vertical coordination among various units.

- Formation of an organizational integrated and uniform culture in order to achieve consensus on central role of customer and considering customers as the key success factor.

- quick access to information and exploiting from work time, retaining customer relationship and service operator through mail, email, telephone contacts, internet and personal meeting for efficient and effective planning and decision making.

phenomenon. Industrial Marketing Management, 33:475-89.

4. Thompson B (2004) Successful CRM: Turning customer loyalty in to profitability on-line. Availabl: WWW.crmgurn.com.

5. Bohling $\mathrm{T}$, Bowman $\mathrm{D}$, LaValle $\mathrm{S}$, Mittal V, Narayandas D, Ramani $G$ and Varadarajan $R$ (2006) CRM Implementation: Effectiveness Issues and Insights. 


\section{Available online at www.managementjournal.info}

6. Kim Hyung-Su, Young-Gul Kim, Chan-Wook Park (2010) Integration of firm's resource and capability to implement enterprise CRM: A case study of a retail bank in Korea. Decision Support Systems 48:313-22

7. Stefanou C, Sarmaniotis C and Stafyla A (2003) CRM and customer-centric knowledge management: An empirical research. J. Business Process Management, 9(5):617-34.

8. Wan W, Luk C and Chow C (2005) Customers' adoption of banking channels in Hong Kong. Int. J. Bank Marketing, 23(3): 255-72.

9. Xu M, Walton J (2005) Gaining customer knowledge through analytical CRM. Industrial Management+DataSystems 105(7):955-72.

10.Fox T, Stead S (2001) Customer Relationship Management: Delivering the Benefits, White Paper, CRM (UK) and SECOR Consulting, New Malden.

11.Sin LYM, Tse ACB, Yim FHK (2005) CRM conceptualization and scale development. Int. J. Marketing 39(11/12):1264-90.

12.Lee J, Chow R, Sin L and Tse A (2000) Relationship marketing: the Chinese way", Business Horizon, 43(1):16-24.

13.Ryals L, Knox S (2001) Cross-functional issues in the implementation of relationship marketing through customer relationship management. European Management Journal 19(5):534-42.

14.Jain D, Singh SS (2002) Customer lifetime value research in marketing: a review and future directions", J. Interactive Marketing 16(2):34-46.

15.Dyche J (2002) The CRM Handbook: A Business Guide to Customer Relationship Management, Addison-Wesley, Upper Saddle River, NJ.
16. Agarwal A, Harding DP, Schumacher JR (2004) Organizing for CRM”, McKinsey Quarterly 3:80-91.

17.Nykamp M (2001) The Customer Differential: The Complete Guide to Implementing Customer Relationship Management, AMACOM, New York, NY.

18.McGovern T, Panaro J (2004) The human side of customer relationship management. Benefits Quarterly 20(3): 26-33.

19.Ghodeswar BM (2001) Winning markets through effective customer relationship management. in Sheth JN, Parvatiyar A, Shainesh G (Eds), Customer Relationship Management: Emerging Concepts, Tools and Applications, Tata McGrawHill, New Delhi, 71-8.

20.Oligvy One/Qci (2001) Is Customer (Relationship) Management Working For You? Http://Www.Ogilvy.Com/Viewpoint/Pdf/V5whitepap er .Pdf

21.Sigala M (2005) Integrating customer relationship management in hotel operations: Managerial and operational implications. Int. J. Hospitality Management 24(3):391-413.

22.Azari A (2008) Assessment of Factors Leading to Customer Relationship Management Success, MA Thesis, Lulea University Of Technology.

23. Curry A (2004) Evaluating crm to contribute to TQM improvement-A cross-case comparison / Curry A., Kkolou E. The Tqm Magazine 16(5):314-24.

24.Chen IJ (2003) Understanding customer relationship management: People, process and technology. Business Process Management Journal $9(5): 672-88$. 